\title{
The Four-Sided Triangle of Ethics in Bioprospecting: Pharmaceutical Business, International Politics, Socio-Environmental Responsibility and the Importance of Local Stakeholders
}

\author{
Janna Rose ${ }^{1, *}$, Cassandra L. Quave ${ }^{2}$ and Gazi Islam ${ }^{3}$
}

\author{
${ }^{1}$ Department of Management, Technology, and Innovation, Grenoble École de Management, 12 rue \\ Pierre Sémard, 38000 Grenoble, France \\ ${ }^{2}$ Center for the Study of Human Health, Emory University, 550 Asbury Circle, Candler Library 107, \\ Atlanta, GA 30322, USA \\ ${ }^{3}$ Department of People, Organizations, and Society, Grenoble École de Management, 12 Rue Pierre \\ Sémard, Grenoble, 38000 France \\ ${ }^{*}$ Corresponding author \\ \E-mail adresses: JR (janna.ROSE@grenoble-em.com), CLQ (cquave@emory.edu), GI \\ (gazi.ISLAM@grenoble-em.com)
}

Ethnobiology and Conservation 2012, 1:3 (4 October 2012)

ISSN 2238-4782

ethnobioconservation.com

doi: 10.15451/ec2012-8-1.3-1-25

\section{Abstract}

Bioprospecting, a vital step in the pharmaceutical production process, is also one of the most controversial and socially complex aspects in the pharmaceutical industry. The current conceptual paper reviews and theorizes this controversial sector by laying out the key elements of social, political and economic conflict involved in bioprospecting, from the point of view of the diverse stakeholders involved in the activity. First, we discuss the bioprospecting phenomenon as a high-risk, initial-stage research and development (R\&D) activity that involves ethical, legal and economic uncertainties. After describing these uncertainties, we show how they are exacerbated by the unique cognitive frames that the main actors in this area - private companies, government actors, social and environmental activists, and local communities - use in framing the motives, norms, and rights surrounding bioprospecting. Juxtaposing actors in this way allows an opening for potential dialogue among the different stakeholders, and we follow our exposition by sketching a model for increased cooperation. Our model highlights the unique contributions of each actor, suggesting that a socially responsible form of natural resource use can promote both local and global benefits. Lastly, we discuss how bioprospecting can be utilized as a key tool in ethnobiological conservation efforts by aiding local stakeholders in the creation of economic value for their traditional knowledge and environmental assets.

Keywords: Corporate Social Responsibility - Intellectual Property - Benefit Sharing - Local Stakeholders-Biotechnology 
Rose et al. 2012. The four-sided triangle of ethics in bioprospecting: Pharmaceutical business, international politics, socio-environmental responsibility and the importance of local stakeholders. Ethnobio Conserv 1:3

How can we present a proposal intended not to say what is, or what ought to be, but to provoke thought...to arouse a slightly different awareness of the problems and situations mobilizing us? (Stengers, 2005: 994)

\section{Introduction}

In recent years, the ethical, social and political issues surrounding bioprospecting in the pharmaceutical industry have come to the forefront of public discussion (see e.g., Lanoszka 2003). While bioprospecting provides companies with leads for profitable new drugs (Beattie and Ehrlich 2001), the source communities for biological samples often consider such activity biopiracy. Biopiracy, or the unethical or exploitative use of local biodiversity (Nazarea 2006; Shiva 1997), is the controversial underbelly of bioprospecting, defined as the search for novel genetic resources or compounds from natural areas (Castree 2003). Disentangling bioprospecting from biopiracy has become increasingly difficult since the 1992 Rio Summit (i.e. the United Nations Conference on Environment and Development, UNCED) led many biodiversity-rich nations to claim sovereignty over their natural resources (Blaustein 2006; Merson 2000). The resulting struggles between governments, corporations, bio-tech firms, researchers, non-government interest groups, and local (often economically disadvantaged and marginalized) people are fraught with ethical complications concerning property rights, recognition for intellectual contribution, benefit sharing, and respect for the autonomy for all actors involved (Soejarto et al. 2005).

Bioprospecting is the epitome of a cross-cultural, multi-national ethical controversy, and yet it is a field of corporate social responsibility (CSR) that has not been deeply explored. A thorough search of peer-reviewed ethics journals results in a handful of related yet indirect publications on the subject (Blowfield 2005; Boyd et al. 2003; Hayden 2007; Isaac and Kerr 2004; Lanoszka 2003; Millum 2010; Rausser and Small 2000; Safrin 2004; Schuklenk and Kleinsmidt 2006; Warner 2006). Few managers or legal advisors have experience, let alone expertise, in bioprospecting agreements in the burgeoning industry of biotechnology and pharmaceuticals (Young 2009). While companies may be driven by profit motives, they must also adhere to strict healthcare and medical research standards in their research. Besides profit generation, companies can create value for society by producing healthcare products that save and improve lives. Nonetheless, the pharmaceutical sector is fraught with risks (e.g., complicated regulatory hurdles and ambiguous property mandates), high expenses, and long-term goals, with the expected returns on investment accordingly high. Such high stakes research projects may heighten the political and ethical tensions that can surround bioprospecting.

Some of the above-mentioned risks result from property rights disputes, transnational border-crossings, and multi-cultural encounters, with source materials found among one cultural group but developed by another (ten Kate and Laird 2000a). Such cultural transactions are often overlaid and reinforce pre-existing power differences between groups, when bioprospecting occurs in less developed countries and the profits are generated by developed country firms. In some cases, foreign researchers have failed to formally recognize the key contributions of local groups in the production of pharmaceutical knowledge (Hayden 2007; Nigh 2002). In other cases, economically less developed but biodiversity-rich countries have attempted to develop biotechnological infrastructures to increase the value-added potential of their natural resources (Cragg et al. 1999; Lewis et al. 2011; Strangeland et al. 2008). 
Rose et al. 2012. The four-sided triangle of ethics in bioprospecting: Pharmaceutical business, international politics, socio-environmental responsibility and the importance of local stakeholders. Ethnobio Conserv 1:3

However, the development of local R\&D (Research and Development) infrastructure is difficult because of the high expense and risk, as well as difficult access to equipment, educated researchers, and necessary materials. In some cases, histories of resource exploitation may leave government officials with a deep mistrust of both academic researchers and pharmaceutical companies from more affluent countries (Barkan 2007; Roopnaraine 1998; ten Kate and Laird 2000a).

As can be seen, bioprospecting involves diverse international actors and stakeholders. Each of these brings their own conceptions of and interests in property rights, legal terms, long-term goals, and ethical considerations. The current conceptual article begins from the premise that the contested nature of ethical issues in this sector makes it an interesting and informative site for business ethics scholars. Here, we review literature describing bioprospecting in terms of business, government, academic, NGO, and local contexts. By examining divergent perspectives from the various stakeholders involved, we hope to show how bioprospecting raises important questions about the relations between business and society, the ethical responsibilities of companies, the role of states in simultaneously promoting innovation and protecting local communities, and the cultural and biological richness of local knowledge that, given the proper institutional supports, can contribute sustainably to global health solutions.

In effect, we will present the positions of three sets of stakeholders that are most often included in legal contractual discourse involving bioprospecting (Isaac and Kerr 2004; Secretariat of the CBD 2011; Young 2009). These include 1) the biotechnological and pharmaceutical companies, 2) the national governments of source countries, and 3) the socio-environmental perspective of special interest groups, non-governmental organizations (NGOs) and researchers from academic institutions or small research groups. We will also argue that an additional set of actors-the local community members who assist bioprospectors in initial field studies-are unfairly overlooked as stakeholders in this research endeavor, and constitute the "fourth side" of the ethics of bioprospecting (Isaac and Kerr 2004; Mauro and Hardison 2000).

The remainder of our paper unfolds as follows: After a brief description of the bioprospecting process, we discuss the current process-dependent controversies in bioprospecting. Next, taking a multi-perspective approach (e.g. Fischer 1986), we juxtapose views from corporate, government, academic, and local actors and attempt to synthesize these diverse perspectives in a model, which we present in Figure 2. Attempting to navigate an ethical path between these perspectives gives rise to a series of conceptual conflicts between groups, which we discuss in the subsequent section. Lastly, we explore some possibilities for avoiding such conflicts through capacities for change, attempting to contribute to possible future understanding between these diverse actors.

\section{Bioprospecting as an ethically fraught area}

Bioprospecting is the first step in a complex, long-term drug development process that can create various misunderstandings at different moments during the process (Kate and Laird 2000; Merson 2000). Companies must gain legitimate access to resources that may have ambiguous legal standings due to their multiple uses (e.g. food, medicine, religious) amongst different local communities across different legal jurisdictions (Kate and Laird 2000b; Schuklenk and Kleinsmidt 2006). Also, they might become highly valuable (generating billions of dollars of revenue per 
year) after more than a decade of chemical and pharmacological investigations, or they may generate no revenue. Determining which resources to invest in becomes a complex selection process, but using the research of ethnobotanists, ethnopharmacologists and other anthropologically informed field researchers can be a selective funnel for determining species that are already used as medicines in other cultures (Heinrich 2000). Termed the "ethnobotanical approach to drug discovery" (Cox and Balick, 1994), this approach has already led to the discovery of high-impact drugs (Koehn and Carter 2005) such as aspirin (drawn from willow bark), digitoxin (a congestive heart failure drug drawn from foxglove) or quinine (drawn from the cinchona tree) for malaria. Although hailed as medical "discoveries", such drugs were derived from the traditional knowledge of the local people who used them as environmental resources for their own healthcare (Cox and Balick 1994).

Because natural evolutionary and co-evolutionary processes can select for functional medicinal features of plants, using such plants can be more effective and often safer than man-made compounds (Koehn and Carter 2005). Specifically, natural products offer a distinct advantage over their synthetic counterparts because of their rich structural diversity, chirality, and extensive functional group chemistry (Gibbons 2008). Thus, botanical natural products are often associated with higher success ("hit") rates for biological activity, as they evolved to bind with other organisms' molecular targets in self-defense efforts against microbial pathogens and herbivores, to enhance attraction of pollinators and seed dispersers, and in resource competition with other neighboring species (Walters 2011). This evolutionary process of finding "hits" can thus be leveraged by companies searching for similar solutions to those faced by natural species.

Companies that develop drugs, then, have a variety of possibilities in how to go about developing novel medicines. In the past, resources were generally open, but with the ratification and implementation of the Convention on Biological Diversity (CBD) at the 1992 Rio Summit, the pharmaceutical industry has begun to shy away from ethnobotanical field studies because of the difficult legal and political issues.

\section{Academic and Corporate Perspectives on Bioprospecting}

Scholarly attempts to discuss ethics in the pharmaceutical field have included treatments of ethics in marketing for pharmaceuticals and healthcare (Rotfeld 2005; Wazana 2000), but most bioethical inquiries in the pharmaceutical and biotechnological industry have focused on end-products such as genetic testing, enhancement, and privacy, stem cell research, cloning, and antibioterrorism technology (Eaton 2004; Finegold 2005). Corporate ethical concerns around genetically-modified crops and enhanced pesticide toxins revolve around pollution and public health issues (Dybas 2003; Mauro and Hardison 2000). These discussions have involved the ethical ramifications concerning propriety rights regarding genetic information, for example (Blaustein 2006; Hayden 2007; Eaton 2004; Holloway 2006).

While public health and intellectual property debates around genetic information dominate the ethical spectrum (Blaustein 2006; Eaton 2004; Finegold 2005; Holloway 2006), ethical issues pertaining to the intercultural contact surrounding early-stage bioprospecting are difficult to come across in ethical scholarship (Rosendal 2006). In terms of corporate social responsibility (CSR) actions, several pharmaceutical companies have integrated CSR into production and research practices (Lindgreen et al. 2009a) and at the end of the bioprospecting 
Rose et al. 2012. The four-sided triangle of ethics in bioprospecting: Pharmaceutical business, international politics, socio-environmental responsibility and the importance of local stakeholders. Ethnobio Conserv 1:3

process by selling or donating products to poor or marginalized groups in need of healthcare.

To provide a few illustrations, Merck announced in September 2011 that it will make maternal care and obstetrics a focal issue for CSR (www.merckformothers.com), working with the UN to provide accessible treatment for women in poor regions. Royal DSM, a Dutch chemical company, donates nutritional supplements and health foods in conjunction with the World Food Programme (Beard and Hornik 2011), and Brazilian managers of Proctor \& Gamble pushed for less expensive quality products that could help poorer individuals live more comfortable lives (Kanter 2011). In 2002, Novartis established a non-profit research center in Singapore to study diseases that most commonly affect tropical, less developed regions and are neglected in treatment research in more developed countries (http://www.nibr.com/research/developing_world/NITD/index.shtml). Novartis states in its 2010 Global Reporting Initiative (http://www.novartis.com/downloads/corporatecitizenship/2010-GRI-report.pdf) that it supports the CBD and works to maintain recognition of national sovereignty over resources and to develop education and drug research opportunities for scientists in other countries, thereby simultaneously contributing to social and environmental responsibility.

That said, virtually no large scale bioethical inquiry or major corporate action has been conducted around the initial, pre-clinical stage of pharmaceutical bioprospecting (Kate and Laird 2000b) where much of the inter-group tensions surrounding extraction and exploitation of resources potentially occur. These initial stages remain a black box for both pharmaceutical companies and scholars. This continued negligence by ethics scholars does a disservice to the local stakeholders who may be the victims of ethically precarious corporate behavior. In areas such as bioprospecting, where legal issues are in a state of flux, ethics is of particular importance. As Wines (2008) points out, "...ethical issues start, in general, where the law ends" (p. 483). For the past 20 years, property rights in bioprospecting have been ambiguous, and ambiguity often opens a space for biased interpretations in business organizations, where the interests of the firm are usually favored (Cunha et al. 2010; Edelman 1992).

A major concern of this paper is to recognize the centrality of corporate ethics with regard to local actors and communities in the pharmaceutical development sector. Following Aguilera et al. (2007), we note the importance of understanding actors' motivations at multiple levels, including micro (individual), meso (organizational), macro (national), and supra (transnational-intergovernmental entities and corporate interest groups and NGOs). While the interactions between these actors are diverse and complex, we note the conspicuous absence of local suppliers from the discussion, a group that has significant bearing in bioprospecting, and indeed, in many pro-social and pro-environmental networks (Maybury-Lewis 1997; Posey 1996). By local suppliers, we refer to the villagers, rural inhabitants, and indigenous people who provide knowledge of natural resources, access to them, and who run the risk of exploiting their resources (which they depend on for life-and-death situations) if an outside stakeholder harvests them unsustainably or patents them (Greene 2004; Kate and Laird 2000a). Given the local group's importance as a part of the medicinal production process, the current paper remedies the relative absence of studies of such groups by recognizing their centrality to the story of bioprospecting and pharmaceuticals. 
Rose et al. 2012. The four-sided triangle of ethics in bioprospecting: Pharmaceutical business, international politics, socio-environmental responsibility and the importance of local stakeholders. Ethnobio Conserv 1:3

\section{The Bioprospecting Process}

Many natural resources are still unknown throughout the world, and most resources have not been tested for medicinal purposes. For example, there are about 400,000 known species of flowering plants with another 40,000 to 80,000 estimated unknown species (Joppa et al. 2010). Less than 1\% of these plants have been extensively studied in a laboratory (Cutler and Cutler 2000; Newman and Cragg 2007). Thus, bioprospectors who collect specimens at random might find new species for science, but the local people in that area might have already known about that plant (Mauro and Hardison 2000; Posey 1996). If a bioprospector works with local people in an area, and these people are accustomed to using the local flora and fauna for medicines, then their knowledge has acted as a filter to pinpoint plants or animals that might be medicinal.

In Figure 1, the process of bioprospecting is shown with emphasis on the initial stages.Often these initial stages are lumped into a "R\&D" box or a "pre-clinical research" box in a processual diagram in the literature. However, these pre-clinical stages are crucial for drug development. They are also less expensive (\$2-4 million) when compared to the enormously expensive Clinical Trials stage of research (estimated $\$ 800$ million) that often take seven or more years to complete (Verkman, 2004). The pre-clinical stages in bioprospecting, however, are the riskiest. While thousands of species might be collected, and each species has hundreds of chemicals, only a handful of extracts and resulting compounds will be found to treat a specific disease or symptom. Part of this limitation is the science. Researchers are constantly improving their assays and screens, using different human targets (a protein that folds incorrectly or the absence of a needed receptor) as well as targets in pathogenic organisms (such as bacteria, viruses, or parasites). As scientific understanding of disease processes increases, the assays for testing the efficacy of compounds for different diseases also increase in scope and number.

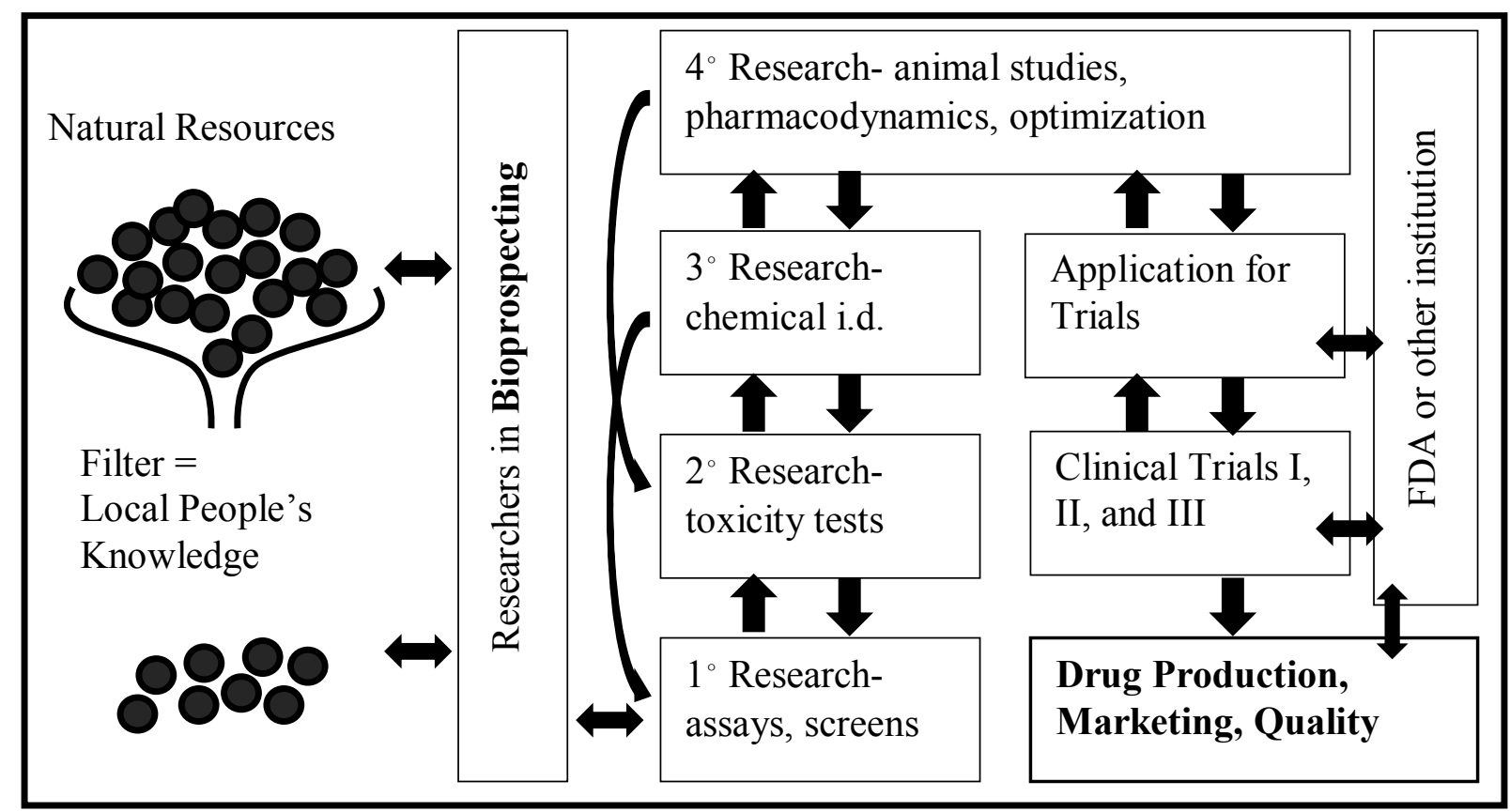

Figure 1. The lengthy and complex bioprospecting process. 
Rose et al. 2012. The four-sided triangle of ethics in bioprospecting: Pharmaceutical business, international politics, socio-environmental responsibility and the importance of local stakeholders. Ethnobio Conserv 1:3

After a researcher conducts fieldwork to collect natural specimens, chemicals or proteins are extracted from the specimens. These extracts are screened for effectiveness against one or more diseases or pathogens. If they exhibit favorable activity, they are further tested for toxicity (against human or mammalian cells), and they are chemically analyzed to identify the one (or sometimes multiple) chemicals or molecules that are responsible for their activity. This can take several months to a few years to complete, and at any stage, the compound might be dropped for showing toxicity, having too complex a chemistry, solubility (and thus delivery) concerns, or already being known.

If the chemical or molecule is identified and tests show that it is effective and non-toxic, then the pharmacodynamics and pharmacokinetics will next be explored, as well as the specific mechanism of action with the target of a disease. This is often carried out using animal testing and basically means that researchers have to pinpoint exactly how the molecule will act in the human body and how the body will respond to it. This also means that researchers have to know exactly how the molecule is interacting with the target in order to treat the disease. Researchers might also slightly alter the molecule at this point to optimize these interactions.

At this stage in development, a molecule is seen as very promising. Its value has been increasing at each stage in the R\&D pipeline, although it is difficult to enumerate the value. This might be a critical point for large firms to consider purchasing or investing in the product's future R\&D (Amir-Aslani and Mangematin 2009; McGrath and Nerkar 2004). Indeed, if the molecule is to continue to clinical trials, major funding allocations must be met, as this is the most expensive part of the drug development process. Most academic research laboratories or small biotechnology firms do not have enough monetary resources available to pursue clinical trials. In fact, even the pre-clinical stages of development that meet regulatory standards often require costly GMP (good manufacturing practice) production of the compound(s) and GLP (good laboratory practice) testing that is typically outsourced to large CRO's (contract research organizations) that specialize in this field. Thus large firms with substantial capital devoted to R\&D are increasingly necessary in this lengthy, risky process, as they have the assets to carry them through the short term until expected (high) revenues can be generated.

A firm must apply for permission to conduct clinical trials through the US's Food and Drug Administration (FDA) or another similar institution (in Europe or other countries). The regulations of each respective regional institution must be met in order for a drug to be marketed and sold in that jurisdiction. The FDA protocol is considered to be the most rigorous and most expensive to complete. Clinical trials involve at least three stages, using different samples of the population (a few healthy individuals, the very sick, and the population at large). Participants in the trials are usually compensated for their time and any negative effects. If all three stages of trials show that the drug is beneficial in treating disease and does not cause serious side effects, then an application for approval of the drug must be compiled and submitted again to the FDA or governing health institution of a region. This is the point when a drug is launched onto the market. Production quality and standards must be upheld, and the product must be packaged, marketed, and advertised. Well after a drug is approved, the FDA continues to check safety and quality standards of drugs and biotechnological products on the market. On average, it is estimated that the expense of bringing a new drug from the discovery phase, through the FDA regulatory hurdles, and to market ranges from approximately $\$ 800$ million to $\$ 2$ billion USD. 
Rose et al. 2012. The four-sided triangle of ethics in bioprospecting: Pharmaceutical business, international politics, socio-environmental responsibility and the importance of local stakeholders. Ethnobio Conserv 1:3

Throughout the process described above, different stakeholders corporations, governmental and non-governmental institutions, activist groups, and local actors- frame the relevant ethical issues according to their diverse institutional logics (e.g. Murrey 2010).

\section{Triangulating Different Perspectives in Bioprospecting}

In the literature of bioprospecting ventures, usually three main actors and the perspectives are represented (Young 2009). These include the pharmaceutical or biotechnology firms, the national governments of the source countries, and also a socio-environmentally derived opposition. Here, we will discuss each in turn, suggesting that a fourth group, local actors, be included in this discussion.

\section{The Pharmaceutical and Biotechnological Companies}

Although the goals of pharmaceutical companies usually involve increased profits, meeting health concerns is also a crucial objective for many companies. In many ways, the health care goals of firms in the biotechnological industry often align with instrumental motives that focus on company investments and returns (Aguilera et al. 2007).

Even if companies with a broad ethical vision commit themselves to being responsible to their wider stakeholders, exactly who is a stakeholder in bioprospecting is a difficult question to answer. Generally, companies are responsible to their employees, investors, consumers, suppliers, and the local communities in which they operate (Campbell 2007; Lindgreen et al. 2009b). However, since bioprospecting involves collecting data and materials from possibly foreign locations, local communities as stakeholders might also incorporate these foreign groups. In such a case, a key question becomes how such additional stakeholders are put on the corporate agenda, and how their voices become heard.

For bioprospecting, an ethical approach might bridge some of the gaps in stakeholder inclusion. According to Wines (2008, p. 487), "Ethics... is the cognitive, analytical, systematic and reflective application of moral principles to complex, conflicting or unclear situations." Deriving from ethical considerations, companies often select methods to engage in CSR. However, "...socially responsible corporate behavior may mean different things in different places to different people and at different times, so we must be careful in how we use the concept and how we define it (Campbell 2007, p. 950)." Campbell (2007) defines corporate social responsibility (CSR), at a bare minimum, as corporations that do not intentionally harm their stakeholders and who rectify any harm should it be brought to their attention.

Additionally, one of the original definitions of CSR (Davis 1973: 312) still remains applicable today. CSR is "the firm's considerations of, and response to, issues beyond the narrow economic, technical, and legal requirements of the firm to accomplish social benefits along with the traditional economic gains which the firm seeks." In current world politics, the recognition of sovereign rights over natural resources for each country could lead to a high value for medicinal plants, novel crops, or other yet-unknown products. In turn, this could give an economic incentive to the conservation of natural resources and wild habitats in these same countries.

Bioprospecting, as an economic venture, is permeated with social values, historical injustices, and potential back-firings. Thus, anyone who engages in bioprospecting ought to have a firm understanding of the social and political 
Rose et al. 2012. The four-sided triangle of ethics in bioprospecting: Pharmaceutical business, international politics, socio-environmental responsibility and the importance of local stakeholders. Ethnobio Conserv 1:3

implications of their actions. However, as many authors have pointed out, (e.g. McHugh 1988; Wines 2008), businesses have tended to neglect the wider social implications of their operations. Ideas around CSR may have had little effect in redefining the purpose of business because of the pre-eminence of values such as profit maximization, free trade, and corporate privileges (Blowfield 2005). While the principle values of businesses go un-questioned in businesses, they may not be shared by the local communities with whom these companies have to interact, negotiate, and develop relationships (Kate and Laird 2000a; Young 2009).

In businesses and corporations, maximizing profits and shareholder value are the imperatives of the contractarian view of the firm, and these objectives take precedence over responsibility (Jensen 2002). Past studies in economic regulation (e.g., Stigler 1968), comparative political economy, and transaction cost analysis (North 1990; Williamson 1985) support the belief that businesses should act opportunistically, maximizing value at all costs.

Campbell (2007) offers eight possible reasons why corporations might or might not act in responsible ways. 1) When a corporation is experiencing weak financial performance or during a volatile economic environment, companies will act to increase short-term profits, thereby disregarding socially responsible behavior. 2) When there is either too much or too little competition, 3) when state regulations are strong and well-enforced, especially when the regulations were developed in open dialogues with members of corporations, government, and other relevant stakeholders, 4) when operating in industrial fields where self-regulation is wellorganized and effective, especially in countries where property rights, court systems, and associative governance is well developed, 5) when corporations are held responsible by NGO's, social movement organizations, the press, or other mobilized private, independent groups, 6) when corporations operate within an environment that calls for responsible behavior as a norm, such as in publications or education curricula, 7) when a corporation is a member of a trade or employer association and that association promotes social responsibility, and 8) when involved and engaged in dialogue with unions, employees, community groups, investors, or other stakeholders in an institutionally recognized manner corporations are more likely to act responsibly.

In bioprospecting, pharmaceutical companies might not be highly motivated to engage in CSR behavior since the industry is fraught with high risks, high costs, longterm end games, and high product standards and quality controls. All of these variables might decrease the instrumental motivation for CSR activity in the firm (Campbell 2007). In addition to technological difficulties, the legal issues that stem from the CBD serve as impediments to action, making the process even more risky as legality becomes questionable, eroding guarantees that countries will remain liable once research is begun. Under the CBD, national governments could pull the rug out from under the company at any time by withdrawing protection of patents or denying access to resources.

\section{The National Governments of the Source Countries}

In the current context, the key source country actors involve governmental officials, park service rangers, representatives of indigenous groups, and lawmakers. In some instances, a specific institution is mandated by a government to be in charge of bioprospecting activities and benefit-sharing contracts (Bonn Guidelines 2002; Young 2009). 
Rose et al. 2012. The four-sided triangle of ethics in bioprospecting: Pharmaceutical business, international politics, socio-environmental responsibility and the importance of local stakeholders. Ethnobio Conserv 1:3

The goals of a national government are often relational (Aguilera et al. 2007). Government actors are motivated to strengthen and intensify relationships between different groups and nations in order to increase competition, increase investments and revenues, and to protect resources for sustainable use. Many national governments, at least in their discourse, are responsible to their collective citizenry (Rosendal 2006; Scott 1998). The CBD recognized the sovereign rights of each nation over its natural resources, establishing the responsibility of each country's government to utilize these resources for the good of the citizenry, and to manage their resources in a sustainable manner so as to create public goods without harming constituents or reducing well-being in future time periods.

To illustrate, during the 1970s in Mexico (Hayden 2008), President Luís Echeverría de-legitimized foreign patents and began funding domestic research into pharmaceutical drugs and medicinal plant development. He worked with campesinos, or peasants, who provided raw plant materials in order to bring them into national politics, accepting them and giving them a sense of belonging in the new national government. The next president quickly dropped these measures. In the following decades, developing countries dealt with economic upheaval and political strife, and during these times the peasants or people of lower socio-economic value began to politicize. In former colonies, the indigenous peoples began voicing their rights to participate in public life on their own terms, maintain autonomy, and able to either govern themselves or contribute to the development of their respective countries. After the 1992 CBD, indigenous groups began claiming different types of rights, including knowledge of natural resources, lands, and agricultural land races. Thus, the model of government regulation involving the inclusion and participation of lower socio-economic groups, such as campesinos, shifted to indigenous groups trying to consolidate recognition of their separate identities from the state and reconfiguration of their relationships to the land and natural resources (see Escobar 1997; Posey 1985, 1996; Greene 2002).

The CBD claimed that nations held sovereignty over their natural genetic resources, and nations have been trying to interpret whether this means that the plants used within the country belong to the nation as a whole or to particular groups within the country. Some researchers have claimed that plant-use within countries has been homogenized for centuries, and therefore the pharmaceutical repertoire has been "nationalized" (Hayden 2003). Thus, the priorities of the nation-state should take precedence over sub-national groups, even if sub-national cultures were the origins of the medical compound, an interpretation which led to various instances of indigenous backlash (e.g., Harvey 2001; Hayden 2008). Later, indigenous groups who could prove their authentic indigeneity were granted special rights, which further sparked the indigenous rights movement. The question still remains: who, specifically, should benefit from natural resources-individuals, communities, or the nation-state?

More generally, the uses of scientific versus indigenous forms of knowledge constitutes a source of political turmoil for several reasons. First, when considering development propaganda, science may play a role in signaling the modernity and development objectives of a nation (Harrison and Johnson 2009). Second, scientific activities require costly infrastructure, including funding opportunities for basic research ventures, links to private or industrial sectors for applied science, and educational opportunities and the latest technology for citizens to fully participate in a global market (Kursar et al. 2006). Third, applied science and technology are political because they lead to industrial innovations, market reconfigurations, reallocations of 
Rose et al. 2012. The four-sided triangle of ethics in bioprospecting: Pharmaceutical business, international politics, socio-environmental responsibility and the importance of local stakeholders. Ethnobio Conserv 1:3

resources, and other economic processes that shift the balance of power among political actors and interest groups. Also, several nations utilize (or would like to utilize) science and technology for development of health products, a highly politicized topic in many areas of the world.

Several issues dominate the interests of national governments in the bioprospecting process. According to the Bonn Guidelines (2002), there are five main issues which include 1) the institutional infrastructure for dealing with international matters and for providing in-country research and valuation methods, 2) the legality, scope, and uses of contracts, 3 ) the inclusion of the public in the source country and the process of informing any potential property sharers, 4) the actual manner in which benefits are shared and distributed, and 5) the implementation of the contractual agreement and fidelity of the parties involved.

According to the CBD, a country has sovereign rights over its genetic resources, but with these rights comes the responsibility of easing access to the resources for R\&D, either with foreign researchers or, ideally, with domestic researchers. National governments can create incentives to value natural resources through R\&D funding or by getting rid of obstacles to access. Government institutions can be entreated to create a market for products or to devise a certification procedure for legally procured goods. Essential to this process, governments must develop a transparent and fairly simple permit/license procedure of application for access to resources. Ideally, source countries will also pass laws to uphold patents, or to share patents, and viable ways to enforce these mandates.

\begin{abstract}
All of this leads to a basic truth known to all lawyers, government administrators, and commercial entities: If a system is non-functional or imposes insurmountable obstacles to the Parties, it does not matter what the system says - nobody will use it. No sector will be served if the ABS (Access and Benefit Sharing) system becomes unusable or so unwieldy that it discourages or prevents users from seeking $A B S$ through contractual or other instruments (Young 2009, p. 16).
\end{abstract}

The mainstream cultures of nations often utilize biopiracy as a resounding call to arms against foreign attack. In Brazil, a nation with high biodiversity in its Amazonian forest and growing economic incentives, biopiracy is a unique topic in that it garners support from politicians, the military, elites, the public, researchers and indigenous groups simultaneously (e.g. Conklin 2002). According to Conklin (2002: 1058), "Unlike conservation and resource management issues, biopiracy is an environmental issue that is perceived to be consistent with nationalism". However such strategies may lead to negative outcomes for national development if they substitute attempts to create opportunities for in-country resource/drug development and value creation for potential products.

One of the major issues concerning national governments in the bioprospecting process is its transnational aspect. While in a source country, visiting researchers or businesspersons are expected to adhere to the laws of that source country. However, once the researchers or businesspersons return to their home country, the source country might have little legal recourse if the researchers or businesspersons go back on their word. It depends greatly on the laws of the home country. 
Rose et al. 2012. The four-sided triangle of ethics in bioprospecting: Pharmaceutical business, international politics, socio-environmental responsibility and the importance of local stakeholders. Ethnobio Conserv 1:3

If the country with jurisdiction over the user does not require its users to comply with the source country's ABS requirements and/or to engage in benefit-sharing, then the user will not be under any legal obligation after he leaves the source country. Until this issue is addressed, the ABS concept will be legally unstable no matter how uniform national PIC [prior informed consent] and MAT [Mutually Agreed Terms] processes might become (Young 2009, p. 29).

The potential for evading source country laws may foster distrust (e.g. Heller \& Escobar 2003), especially when researchers are from countries that have not ratified the CBD or acknowledged benefit-sharing as a necessary outcome of bioprospecting. The CBD has been recognized in some form (either via ratification, accession, approval, or acceptance) by all recognized nations with the notable exception of the USA. The Holy See and Andorra are the only other nations that have also chosen not to recognize the treaty (http://www.cbd.int/convention/parties/list/). However, in NIH (National Institutes of Health - USA) -funded research for pharmaceuticals, benefit sharing agreements are required at the initial stages of acquiring resources in foreign countries. Moreover, it is considered a professional ethical standard and responsibility of researchers in the field of ethnobiology (including ethnobotany and ethnopharmacology) to promote equitable ABS arrangements (Heinrich 2000). Yet, researchers in the USA are at the same time handicapped in such endeavors as they are not equipped with the legal power of the CBD (Mauro and Hardison 2000) to enforce such actions within their institution, whether it is a private company or academic institution.

\section{The Socio-Environmental Perspective}

The actors involved in promoting socio-environmental responsibilities are diverse and include members of non-governmental organizations (NGOs), specific interest groups, activists, local collaborations, and possibly, academic researchers in biology, ecology, anthropology, political science, sociology, or a number of other fields.

In general, the above groups share a common objective of protecting the environment, marginalized groups of people, or promoting the sustainable use of natural resources (Arenas et al. 2009; Crilly et al. 2008; Peterson 2001). What often motivates actors in this group are social, professional and moral norms regarding progressive social and political change. The responsibilities of NGOs, interest groups, or activists are to try to listen to the needs of local groups and to act to promote their best interests. Also, researchers are usually accountable to funding agencies and academic ethics committees. These actors attempt to accurately represent marginalized groups or the environment in politicized ways that effectively bring about change through legal, social, or economic accomplishments. Overall, members of this group try to demonstrate how the environment, traditional peoples, and their environmentally situated knowledge systems are significant, valuable, and important in today's world (Isaac and Kerr 2004).

In the bioprospecting process, socio-environmental actors are usually foreign actors who try to draw attention to the importance of natural and social resources, i.e. local peoples and their medicinal remedies. Research has shown a close link between biodiversity conservation and poverty traps (Barrett et al. 2011), with 
Rose et al. 2012. The four-sided triangle of ethics in bioprospecting: Pharmaceutical business, international politics, socio-environmental responsibility and the importance of local stakeholders. Ethnobio Conserv 1:3

increased conservation leading to improved social livelihoods, health, and quality of life for local inhabitants.

Of the leading theoretical perspectives in socio-environmental research, the Treadmill of Production model (Gould et al. 2004), World Systems Theory in Ecology (Roberts and Grimes 2002; Roberts and Parks 2007), Political Economy of the Environment (Boyce 2002) and Inequality, Democracy, and the Environment theory (Downey and Strife, 2010) all place the commercial interests of a small percentage of wealthy people, most often from developed countries, as the cause of harm, intentionally or unintentionally, to people and their environmental resources in less developed countries. Stemming from power disparities and social inequalities, the rich and influential elite are able to degrade social relations and misappropriate environmental resources by 1) allowing a few people to undemocratically make decisions for the vast majority, 2) transferring costs to less powerful individuals or groups, 3) blocking the development or transmission of pro-environmental knowledge and beliefs, 4) shaping and limiting the choices and manners in which people can act pro-environmentally (or medically), 5) framing the policies and debates of what constitutes pro-environmental responsibility for corporations or networks, and 6) diverting attention away from anti-environmental activity of harmful organizations or industries (Downey and Strife 2010). Following some accounts (e.g. Downey and Strife 2010; Nazarea 2006), the commercial sector holds a significant degree of responsibility for the effect industrial effect on society and environmental resources, and should be held accountable for acting in ethical or responsible ways.

Researchers from academia run into problems when trying to conduct research in developing countries because of the fears of biopiracy (Kursar et al. 2006, 2011; Mauro and Hardison 2000). Source countries don't trust the academic researchers, who are, arguably, trying to conduct research for the sake of knowledge, because they have been burned by pharmaceutical companies, or they fear being duped. This halts academic research while really having very little effect on large pharmaceutical firms (Kursar 2011) who have the clout and financial backing to deal directly with government officials.

\section{The Fourth Side of the Triangle: Local Communities}

The actors in bioprospecting processes who are local in this context are those from the communities of origin of biopharmaceutical products. Local actors include villagers, peasants, rural inhabitants or indigenous peoples who assist researchers in identifying plants, animals, or minerals that have bioactivity. Local communities often use natural products to treat their illnesses, retaining, reproducing and expanding folk knowledge in ways that make them rich sources for scientific research. They know which environmental resources to turn to due to the existence of a specific set of traditional ecological knowledge (TEK) that is frequently the communal property of the community, and which is often passed down across generations via oral traditions, for example, in the form of stories or learned experiences with elders during childhood and young adulthood (Conklin 2002). Sometimes, these natural resources are potent inhibitors of disease, and may serve as the keys to potential medicines.

During the initial stages of bioprospecting, local groups often interact with biological or anthropological researchers about their beliefs concerning health and illness, cosmology, religion, and healing practices (e.g. Nazarea 2006). In some inquiries, researchers also ask about substances that are used for treatments of 
Rose et al. 2012. The four-sided triangle of ethics in bioprospecting: Pharmaceutical business, international politics, socio-environmental responsibility and the importance of local stakeholders. Ethnobio Conserv 1:3

illness. They may collect sources of treatments with local individuals who might be healers or specialists in herbal remedies, or they might be experienced mothers who have treated their children or other individuals. There are many different kinds of healers, in all cultural groups.

In the US and other countries, gaining approval from internal review boards for human subjects research is a pre-requisite to these interviews and collection activities. Biologists and anthropologists, especially those that have received federal funding, must adhere to strict ethical practices such as obtaining prior informed consent (PIC) before asking anyone about their TEK of local medicinals. These procedures are regulated by the National Institutes of Health $(\mathrm{NIH})$ in the US, which also oversees the human subjects research standards for pharmaceutical and biotechnological clinical trials.

However, during the initial stages of research, the potential commercial value of any of the collected materials is largely unknown. Some academic organizations, especially in the fields of ethnobiology and ethnopharmacology, strongly encourage researchers to lay out a plan for benefit-sharing at this initial stage of inquiry, so that if a drug is eventually made from the collected materials, the local source of knowledge will have rights to a share in profits.

The rural populations that live in isolated "outback" environs and have intimate uses for natural resources frequently include marginalized groups. These groups often persist on the margins of democratic processes (e.g. Agamben 2005; Mauro and Hardison 2000). In some countries, especially the post-colonial societies, the native indigenous populations comprise a miniscule percentage of the general population, thus making it difficult to gain a popular majority in democratic processes. "In Brazil, Native peoples constitute less than one percent of the population, numbering some three hundred thousand in a national population of 173 million-the smallest percentage in any country in the continental Americas. Brazilian Indians only recently gained the right to vote..." (Conklin 2002: 1051). Often, these groups are seen as "backwards" or "anti-developmental" when, in fact, they are groups that are trying to maintain their customs and ways of life. In recent years, the sustainable environmental practices of these groups have been viewed as wise, organic alternatives to industrial, polluting uses of the land (Mauro and Hardison 2000). Coinciding with these practices is a rich knowledge base of the land, its ecology, and the surrounding species and resources that can be acquired for human use, collectively recognized as TEK (Posey 1996).

According to the Bonn Guidelines (2002), contractual agreements for benefitsharing should include local groups that contributed to the valuation of natural resources. The guidelines state,

...benefits should be shared fairly and equitably with all those who have been identified as having contributed to the resource management, scientific and/or commercial process, [including] governmental, nongovernmental or academic institutions and indigenous and local communities. Benefits should be directed in such a way as to promote conservation and sustainable use of biological diversity (Article 48).

Important in this context is the phrase "...all those who have been identified as having contributed..." While initial researchers in bioprospecting readily identify local informants as contributors to this process, later researchers rarely recognize locals as contributors in the process. In fact, 
Rose et al. 2012. The four-sided triangle of ethics in bioprospecting: Pharmaceutical business, international politics, socio-environmental responsibility and the importance of local stakeholders. Ethnobio Conserv 1:3

...most users [or researchers] feel that ABS responsibilities apply only where the user specifically obtained the resource from the source country directly - i.e., by engaging in direct bioprospecting under a permit. They appear to feel that, if the material is acquired from another collector, it is not covered by ABS. This approach appears to create a significant 'loophole.' (Young 2009: p13)

Pharmaceutical companies might view this loophole as a blessing to bypass complicated, time-consuming bureaucratic procedures, but using loopholes can generate more distrust between national governments, local contributors, and pharmaceutical companies (Kate and Laird 2000a). Such distrust would explain the rigidity of source country laws regarding benefit-sharing contracts with foreign researchers and businesspersons.

Conversely, local people are also commonly left out of national governments' plans for distributing funds generated by bioprospecting. The CBD and resulting legal guidelines are not clear on what fiduciary obligations a source-country has to its citizens in matters of bioprospecting (Young 2009). Overall, the local individuals who contribute to novel drug development in its initial stages are often dismissed and overlooked by both large-scale pharmaceutical companies and national governments in the bioprospecting process. Unless they are recognized as individually named inventors on patents resulting from their TEK, the pathway of ABS funds to the appropriate people is not secured. This solution is oftentimes not feasible because the TEK is usually considered the common property of the group, developed over generations - and does not typically fall into the category of being the IP (Intellectual Property) of only a few individuals.

\section{Negotiating Perspectives}

A model for ethical bioprospecting ventures involving large pharmaceutical firms, national governments and local villagers who assist in the bioprospecting process is represented in Figure 2.Topics covered under the ABS agreement include whether the information is to be kept private or made public. Also, the agreements cover how benefits will be shared and when (the mechanisms, types of benefits, and contention plans). Of utmost importance, the ABS agreements resolve property rights issues in a way that addresses each party's concerns. Local stakeholders using natural resources as a source of livelihood should be allowed access to their resources and ideally share in the property rights and, arguably, own a portion (or all) of the intellectual property rights of a potential product. The national government should be able to administer and protect the property rights of the parties involved, allowing researchers to protect their future work and possible products. The parties involved might sometimes consider alternatives (such as open networking) instead of property issues (Belk 2007). If possible, technological information and research protocols could also be shared as the research advances. At regular intervals, information on the progress of the research should be reported to the source country and original local research sites. 
Rose et al. 2012. The four-sided triangle of ethics in bioprospecting: Pharmaceutical business, international politics, socio-environmental responsibility and the importance of local stakeholders. Ethnobio Conserv 1:3

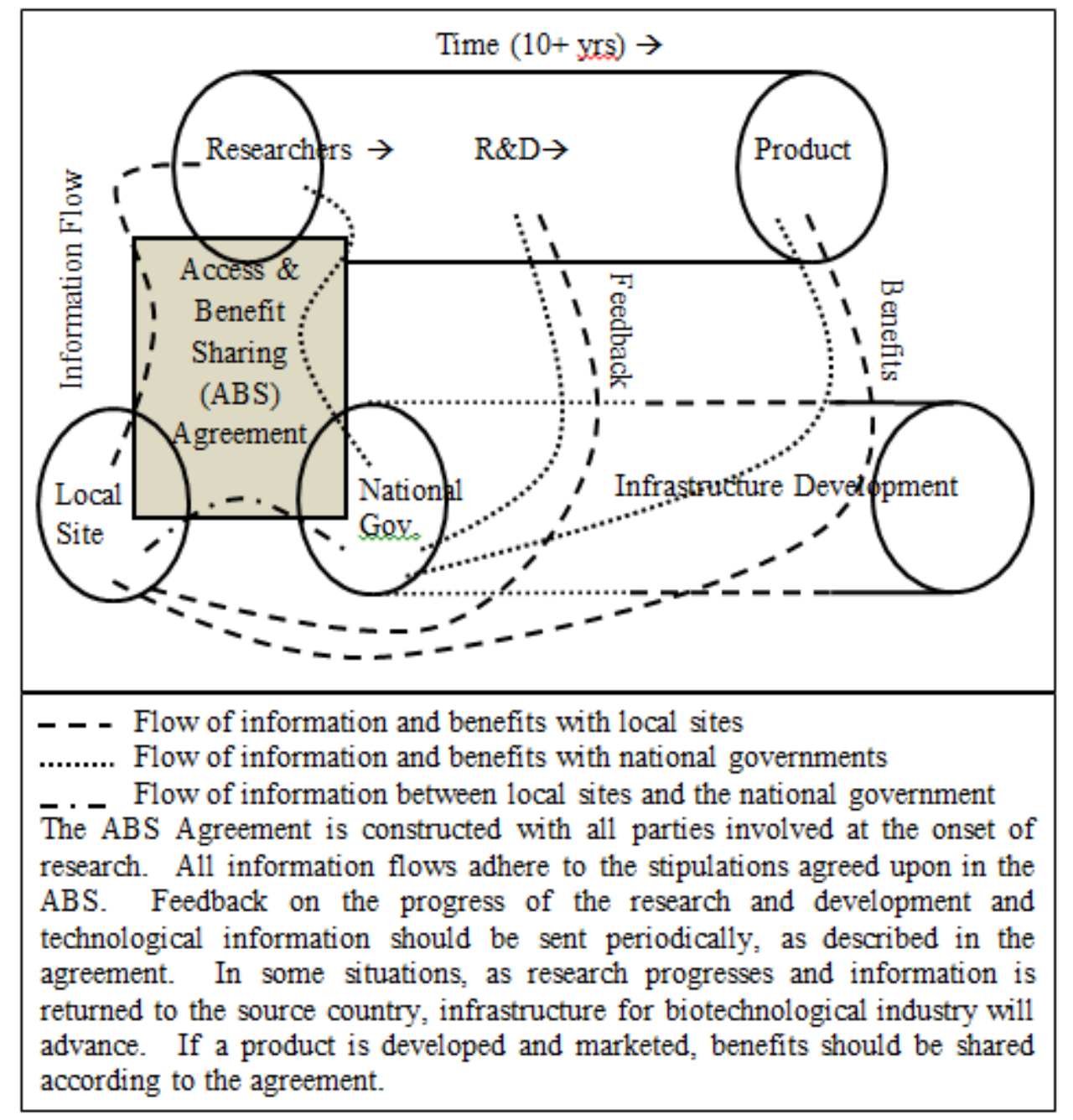

Figure 2. A model for benefit sharing in bioprospecting.

Potential problems with this model include the use of a large pharmaceutical company as initial researchers in the process of bioprospecting. Increasingly, large pharmaceuticals are not engaging in direct bioprospecting ventures because of the legal ambiguity of property rights and fears of parties not fulfilling their obligations or discontinuing agreements. Thus, researchers from academic institutions or small firms are often the first to engage in bioprospecting research. With less funding, manpower, and resources, these researchers are more likely to conduct small studies, and they usually cannot afford to pay in advance for access to natural resources or information. Still, they can draw up an ABS agreement and stipulate what should happen if their research is carried out and another researcher or large firm wants to acquire access to the resources. However, if transnational rules were established for different types of researchers and stakeholders in the bioprospecting process, these contracts could be drawn up and enforced more easily across borders. Moreover, transnational laws would enforce universities, who in fact are the owners of any IP generated by their faculty (the "inventors" on patentable technology), to adhere to such agreements, ensuring that ABS agreements are incorporated in the package of any relevant IP to companies wishing to pursue R\&D for eventual commercialization. 
Rose et al. 2012. The four-sided triangle of ethics in bioprospecting: Pharmaceutical business, international politics, socio-environmental responsibility and the importance of local stakeholders. Ethnobio Conserv 1:3

To date, ABS agreements have varied tremendously in their approach to benefit sharing. In Panama, the National Cancer Institute $(\mathrm{NCl})$ of the US paid for access to plants while also sharing education and technological advances with a Panamanian research institute, thereby helping to develop a research program in the source country (Cragg et al. 1999; Kursar et al. 2006). Over the past two decades Novartis, a large Swiss pharmaceutical company, has entered ABS agreements with several countries, including Brazil, Malaysia, and China. Novartis not only develops local research facilities in the source country, but it also facilitates transnational research exchange with foreign researchers training in different headquarters (Novartis 2011).

In other cases, perhaps ABS agreements should have been considered at some point in the drug R\&D path. For example, in the United States, the cancer drug Taxol (paclitaxel) from the Pacific Yew (Taxus brevifolia Nutt.) was discovered during a National Cancer Institute screening program in which US domestic plants were collected and tested for anti-cancer activity at the Research Triangle Institute (Kingston 2007). Although the medicinal use of this plant has been documented in the Native American ethnobotanical literature for more than 14 distinct Native American (USA) and First Nations (Canada) tribal groups (see Moerman 1998: 551552 ), to the best of our knowledge, no benefit sharing or compensation to these groups has ever been made. Thus, while Taxol $^{\mathrm{TM}}$ has saved countless lives of cancer patients, the original stakeholders of TEK for the medicinal use of this plant have never seen any direct recompense for this knowledge. Some could argue that the discovery was not made based on ethnobotanical knowledge of the plant, but rather a random collection and screen. However, the existence of the ethical conflict (as discussed earlier in our mention of "loopholes" for ABS avoidance) should be further addressed (see Bannister 2009: 305-306 and Kate and Laird 2000b: 73-75 for more on this topic). There are numerous ways for ABS agreements to be drawn up, but an important factor is to remember to include all parties, including any initial local people who use the natural resource for medicines or a livelihood. All too often, the initial stages of bioprospecting research are forgotten as the process of drug development continues over time.

\section{Discussion-Conflicts and Capacities for Change}

Between the perspectives of the different groups involved in bioprospecting, there is sometimes conflict and always a capacity for change. It is important to keep the following points in mind when trying to resolve ethical issues involving CSR in bioprospecting.

\section{Conflicts}

One of the major conflicts in bioprospecting involves property rights (Kate and Laird 2000b). For each group, property rights are important, but for different reasons. A drug development firm wants to make sure that they will be able to corner the market after years, possibly decades, of investments in development and research. Current R\&D pre-approval expenses for a new drug are estimated at $\$ 800$ million (DiMasi et al. 2003). Pharmaceutical firms need to be able to rely on high revenue if they are to legitimize the risk in such high investments. Alternatively, they need to explore new ways to moderate risk or the investment costs of drug development. As for researchers along the R\&D pipeline, their relative contributions should be 
Rose et al. 2012. The four-sided triangle of ethics in bioprospecting: Pharmaceutical business, international politics, socio-environmental responsibility and the importance of local stakeholders. Ethnobio Conserv 1:3

acknowledged and recognized through partial patent ownership. National governments have an interest in gaining competitive advantage through their control of innovative products that, through patent protection, create a legal barrier to entry for competitors (e.g. Porter 1998).

Conflict among the various actors involved in bioprospecting has led to a deceleration in research concerning unknown, un-studied, and un-touched species (Kursar 2011; Mauro and Hardison 2000). With deforestation and habitat destruction a pressing issue, the discovery of genetic resources may be an urgent and timesensitive opportunity. One of the most socially irresponsible conflicts that is highlighted in bioprospecting ventures is the pitfall of viewing indigenous peoples or rural, local groups as backwards and assuming that they have little to offer the national government or drug developers. These stakeholders have long been engaged in drug prospecting and, if recognized and allowed to play a more significant role in the bioprospecting process, might guide R\&D in ways that minimize risk, lag time, and expense.

\section{Capacities for Change}

The opportunity of bioprospecting can lead not only to new drugs, but also can promote diverse networks between stakeholders that contribute their specific knowledge in this complex, risky process. A capacity for change exists in that value is not only created for novel health products but also for citizens that are often marginalized. The social impact of bioprospecting can lend respect to governments and local citizens, allowing for bioprospecting to act as a catalyst for social exchange of ideas and national development.

Kanter (2011) discusses the potential for business innovation, unusual opportunities, and future collaborations when new social relationships are forged and solidified. Especially in biotechnology and pharmaceutical businesses, social issues involving health, access to care, federal standards, multilateral links, and transnational agreements must be addressed, the earlier in the process the better. Managers need social, historical, and ethical training in order to make sense of their business's purpose and to understand how societies' expectations change over time. Understanding the social context of a business is imperative for understanding the responsibilities of a business (e.g. Bird and Smucker 2006). Concerning bioprospecting, recognizing the full list of stakeholders is another use of social theory.

There is the capacity for making incredible profits through novel genetic and chemical resources, if the social and ethical issues surrounding this sector can be carefully navigated. While actors in bioprospecting might be experiencing difficulties in the current legal system, the potential for progress remains significant. Furthermore, the potential for the generation of economic value concerning indigenous intellectual property and environmental resources creates a unique opportunity for both cultural and biological conservation strategies. The use of economic gains from bioprospecting ABS agreements could contribute to the alleviation of economic hardships of local stakeholders. This could have a significant impact on local resource management, especially in developing nations, where environmental resources are often utilized in an unsustainable fashion due to widespread poverty. 
Rose et al. 2012. The four-sided triangle of ethics in bioprospecting: Pharmaceutical business, international politics, socio-environmental responsibility and the importance of local stakeholders. Ethnobio Conserv 1:3

\section{Conclusion: Creating a Balancing Act}

Important in resolving the controversies in bioprospecting is an open discussion that takes into consideration diverse points of view. Pharmaceutical companies, national governments, and local groups with knowledge of natural resources struggle to develop a balancing act that benefits each constituency. Each is connected to the others in a bioprospecting venture, and each set of actors needs to act responsibly in turn. Potential conflicts may arise, but there is capacity for change and improvement.

One of the main sources of contention rests in the inequality, whether real or perceived, in standards for bioprospecting in developed versus developing countries. To obtain equality in social and environmental responsibilities, all stakeholders should be recognized and included in the ABS agreements, including the oftforgotten local individuals, families, and communities who first used natural resources as a common means of healthcare or livelihood. The ABS agreement should detail who receives benefits, what the benefits might include, how the benefits are to be distributed, and when they are to be distributed. Setting these terms ahead of research can prevent misunderstandings and resulting mistrust.

A key element in the controversy surrounding bioprospecting involves property rights. The current system of patenting and property rights is inadequate to deal with the types of natural resources that are used in biotechnology and pharmaceutical research. The genes, proteins, or molecules used in current research do not "fit" into any of the categories of properties in the patenting system. Genes (or proteins, or chemicals) occur across a population, or even across species, and they are necessary for the life of an organism. Similarly, people's lives and livelihoods are connected to the species in which genes or materials are being patented. Local traditional use of plants cannot be hampered or disrupted by patents, but pharmaceutical companies' interests and rights should also be protected. The current IPR (Intellectual Property Rights) system does not function well, stalls research, and is a hindrance. The bottom line is that it needs to be re-vamped.

Bioprospecting can profit from increased dialogue with the humanities and social sciences, particularly those fields such as ethnobiology and medical anthropology, that span both natural and social scientific areas, and highlight social policy and public health issues (e.g. Nazarea 2006). Businesses do not operate in a vacuum; they are part of a social whole (Lock 2004). Understanding this connectedness and using it to consider the well-being all actors involved should lead to ethical decision making and more trustworthy CSR. Ideally, a self-regulated field might emerge after analyzing bioprospecting through various social theories and ethical considerations. If an international system of regulations was ratified, each country would have the same rights to its resources and bioprospectors, both foreign and domestic, would know how to proceed with their activities in a socially and environmentally responsible manner. Local indigenous or rural groups would also be informed of their rights and know what to expect in these ventures.

By acknowledging and working with local groups from the beginning of the bioprospecting process, the end goals of environmental and cultural conservation and protection can be met, which further prevents many social problems. Alleviating social inequalities by providing access to end products, such as new drugs or biotechnologies, is also important, but working at the beginning, at environmental levels, is empowering for local peoples and gives them opportunities for improving their livelihoods. Overall, assisting countries that are rich in biodiversity to develop 
their own resources within domestic institutions would best alleviate social and environmental problems. Building a research and education infrastructure that incorporates bioprospecting for natural resources would not only add value to domestic products and domestic landscapes, but it would also add value to environmental protection and traditional cultural groups who might understand environmental resources in a different manner.

Also, if national institutions prioritized investment in research and drug development at the local and national levels, they would be able to participate in developing health products that are necessary for their citizens, focusing on certain diseases or pathogens that are common in their area. This might shift the focus from resources in developing countries to markets in developing countries. Instead of seeing developing countries as sources for raw materials, they might be viewed as opportunities for developing new products and marketing them. Developing countries comprise the majority of the global population, with billions of people that might be viewed as consumers for marketed products and services (Grayson 2004; Prahalad 2004). There are many business opportunities lying dormant in this sector, especially if opportunities help address the needs of so many people. Bioprospecting can help address domestic health needs and domestic economic development simultaneously.

In the current paper, we have attempted to contribute to a nascent discussion of ethical issues in biosprospecting, sketching an incipient model of the ways in which multiple actors can negotiate their diverse outlooks and objectives. By working together and informing each other of their needs and goals, these actors might be able to work better together and improve CSR and ethical decision making. The resolution of property rights issues and ethical conduct in research can only be brought about when participants in this process talk openly. Perhaps, a resolution of the controversy in bioprospecting will occur with the recent Nagoya Protocol (Secretariat of the CBD 2011), or during the UN's Decade of Biodiversity, 2011-2020. Future collaborations between companies, governments, academic and research institutions, and rural residents can alter the course of human health on a global scale.

\section{References}

Agamben G (2005) The State of Exception. University of Chicago Press, Chicago, USA.

Aguilera R, Rupp D, Williams C, Ganapathi J (2007) Putting the S Back in Corporate Social Responsibility: A Multilevel Theory of Social Change in Organizations. Academy of Management Review 32:836-863.

Amir-Aslani A, Mangematin V (2009) The Future of Drug Discovery and Development: Shifting Emphasis Towards Personalized Medicine. Technological Forecasting \& Social Change doi: 10.1016/j.techfore.2009.09.005.

Arenas D, Lozano JP, Albareda L (2009) The Role of NGOs in CSR: Mutual

Perceptions Among Stakeholders. Journal of Business Ethics 88:175-197.

Bannister K (2009) Human Research Ethics Guidelines as a Basis for Consent and Benefit Sharing. In: Wynberg R, Schroeder D, Chennells $R$ (eds) Indigenous Peoples, Consent and Benefit Sharing: Lessons from the Sans Hoodia Case. Springer, USA, pp. 305-306. 
Rose et al. 2012. The four-sided triangle of ethics in bioprospecting: Pharmaceutical business, international politics, socio-environmental responsibility and the importance of local stakeholders. Ethnobio Conserv 1:3

Barkan E (2007) Genes and Burkas: Predicaments of Human Rights and Cultural Property. In: Silverman H, Ruggles DF (eds) Cultural Heritage and Human Rights. Springer, USA, pp. 189-192.

Barrett CB, Travis AJ, Dasguptad P (2011) On Biodiversity Conservation and Poverty Traps. Proceedings of the National Academy of Sciences 108:1390713912.

Beard A, Hornik R (2011) It's Hard to Be Good: But it's worth it. Harvard Business Review, November, 88-96.

Beattie A, Ehrlich PR (2001) Wild Solutions: How Biodiversity Is Money in the Bank. Yale University Press, New Haven, CT, USA.

Belk R (2007) Why Not Share Rather than Own? Annals of the American Academy of Political and Social Science 611:126-140.

Blaustein R (2006) Genetic Resources and the Convention on Biological Diversity. BioScience 56:560-563.

Bird F, Smucker J (2006) The Social Responsibilities of International Business Firms in Developing Areas. Journal of Business Ethics 73:1-9.

Blowfield M (2005) Corporate Social Responsibility: Reinventing The Meaning Of Development? International Affairs 81:515-524.

Bonn Guidelines (2002) Bonn Guidelines on Access to Genetic Resources and Fair and Equitable Sharing of the Benefits Arising Out of Their Utilization. United National Environmental Programme Convention on Biological Diversity. [http://www.cbd.int/abs/bonn.shtml] Accessed 30 November 2011.

Boyce JK (2002) The Political Economy of the Environment. Edward Elgar, Northampton, MA, USA.

Boyd SL, Kerr WA, Perdikis N (2003) Agricultural Biotechnolgy Innovations versus Intellectual Property Rights-Are Developing Countries at the Mercy of Multinationals? Journal of World Intellectual Property 6:211-232.

Campbell JL (2007) Why Would Corporations Behave in Socially Responsible Ways? An Institutional Theory of Corporate Social Responsibility. Academy of Management Review 32:946-967.

Castree N (2003) Bioprospecting: From Theory to Practice (And Back Again). Transactions of the Institute of British Geographers 28:35-55.

Conklin B (2002) Shamans versus Pirates in the Amazonian Treasure Chest. American Anthropologist 104:1050-106.

Cox PA, Balick MJ (1994) The Ethnobotanical Approach to Drug Discovery. Scientific American 270:82-87.

Cragg GM, Boyd MR, Khanna R, Kneller R, Mays TD, Mazan KD, Newman DJ, Sausville EA (1999) International Collaboration in Drug Discovery and Development: The NCI Experience. Pure Applied Chemistry 71:1619-1633.

Crilly D, Schneider SC, Zollo M (2008) Psychological Antecedents To Socially Responsible Behavior. European Management Review 5:175-190.

Cunha MP, Guimarães-Costa N, Rego A, Clegg SR (2010) Leading and Following (Un)ethically in Limen. Journal of Business Ethics 97:189-206.

Cutler SJ, Cutler HG (2000) Biologically Active Natural Products: Pharmaceuticals. CRC Press, USA.

Davis K (1973) The Case For and Against Business Assumption of Social Responsibilities. Academy of Management Journal 16:312-322

DiMasi JA, Hansen RW, Grabowski HG (2003) The Price Of Innovation: New Estimates Of Drug Development Costs. Journal of Health Economics 22:151185. 
Downey L, Strife S (2010) Inequality, Democracy, and the Environment. Organization \& Environment 23:155-188.

Dybas CL (2003) Bioethics in a Changing World: Report from AlBS's 54th Annual Meeting. BioScience 53:798-802

Eaton M (2004) Ethics and the Business of BioScience. Stanford University Press, Stanford, CA, USA.

Escobar A (1997) Cultural Politics and Biological Diversity: State, Capital, and Social Movements in the Pacific Coast of Colombia. In: Starn O, Fox R (eds) Culture and Social Protest: Between Resistance and Revolution. Rutgers University Press, New Brunswick, NJ, pp. 40-64

Edelman LB (1992) Legal Ambiguity And Symbolic Structures: Organizational Mediation Of Civil Right Law. American Journal of Sociology 97:1531-1576.

Etkin NL (2001) Perspectives in Ethnopharmacology: Forging a Closer Link Between Bioscience and Traditional Empirical Knowledge. Journal of Ethnopharmacology 76:177-182.

Finegold D (2005) Bioindustry Ethics. Elsevier Academic Press, Burlington, MA, USA.

Fischer MMJ (1986) Ethnicity and the Post-Modern Arts of Memory. In: Clifford J, Marcus GE (eds) Writing Culture: The Poetics and Politics of Ethnography.Verso Press, New York, NY, USA, pp. 195-235.

Gibbons S (2008) Phytochemicals for Bacterial Resistance--Strengths, Weaknesses And Opportunities. PlantaMedica 74:594-602

Gould KA, Pellow DN, Schnaiberg A (2004) Interrogating the Treadmill of Production. Organization and Environment 17:296-316.

Grayson D (2004) Corporate Social Opportunity. Greenleaf, Sheffield, UK.

Greene S (2004) Indigenous People Incorporated? Culture as Politics, Culture

as Property in Pharmaceutical Bioprospecting. Current Anthropology 45(2):211-237.

Greene S (2002) Intellectual Property, Resources or Territory? Reframing the Debate over Indigenous Rights, Traditional Knowledge, and Pharmaceutical Bioprospecting. In: Bradley M, Petro P (eds) Truth Claims: Representation and Human Rights. Rutgers University Press, New Brunswick, NJ, USA, pp. 229-249. Harrison CE, Johnson A (2009) Introduction: Science and National Identity. Osiris $24: 1-14$.

Harvey N (2001) Globalisation and Resistance in Post-Cold War Mexico: difference, citizenship, and biodiversity conflicts in Chiapas. Third World Quarterly 22:1045-1061.

Hayden C (2008) Vinculaciones: Pharmaceutical Politics and Science. In: Poole D (ed) A Companion to Latin American Anthropology, Blackwell Publishing Ltd., Oxford, UK, pp. 303-324.

Hayden C (2007) Taking as Giving: Bioscience, Exchange, and the Politics of Benefit-Sharing. Social Studies of Science 37:729-758.

Hayden C (2003) When Nature Goes Public: The Making and Unmaking of Bioprospecting in Mexico. Princeton University Press, Princeton, NJ, USA.

Heinrich M (2000) Ethnobotany and its Role in Drug Development. Phytotherapy Research 14:479-488.

Heller C, Escobar A (2003) From Pure Genes to GMOs: Transnationalized Gene Landscapes in the Biodiversity and Transgenic Food Networks. In: Goodman AH, Heath D, Lindee MS (eds) Genetic Nature/Culture: Anthropology 
and Science Beyond theTwo-Culture Divide. University of California Press, Berkley, CA, USA.

Holloway K (2006) Accidental Communities: Race, Emergency Medicine, and the Problem of PolyHeme®. The American Journal of Bioethics 6:7-17.

Isaac GE, Kerr WA (2004) Bioprospecting or Biopiracy? Intellectual Property and Traditional Knowledge in Biotechnology Innovation. Journal of World Intellectual Property 7:35-52.

Jensen M (2002) Value Maximization, Stakeholder Theory, and the Corporate Objective Function. Business Ethics Quarterly 12:235-256.

Joppa LN, Roberts DL, Pimm SL (2010) How Many Species of Flowering Plants Are There? Proceedings of the Royal Society, Biological Sciences doi: 10.1098/rspb.2010.1004.

Kanter RM (2011) How Great Companies Think Differently. Harvard Business Review, November, 66-78.

Kate KT, Laird S (2000a) Biodiversity and Business: Coming to Terms with the 'Grand Bargain'. International Affairs 76:241-264.

Kate KT, Laird S (2000b) The Commercial Use of Biodiversity: Access to Genetic Resources and Benefit-Sharing. Earthscan Publications, London, UK.

Kingston DGI (2007) The Shape of Things to Come: Structural and Synthetic Studies of Taxol and Related Compounds. Phytochemistry 68:1844-1854.

Koehn F, Carter GT (2005) The Evolving Role of Natural Products in Drug Discovery. Nature 4:206-220.

Kursar TA, Caballero-George CC, Capson TL, Cubilla-Rios L, Gerwick WH, Gupta MP, Ibañez A, Linington RG, Mcphail KL, Ortega-Barría E, Romero LI, Solis PN, Coley PD (2006) Securing Economic Benefits and Promoting Conservation through Bioprospecting. BioScience 56:1005-1012.

Kursar TA (2011) What Are the Implications of the Nagoya Protocol for Research on Biodiversity? BioScience 61:256-257

Lanozska A (2003) The Global Politics of Intellectual Property Rights and Pharmaceutical Drug Policies in Developing Countries. International Political Science Review 24:181-197.

Lewis D, Bell SD, Fay J, Bothi KL, Gatere L, Kabila M, Mukamba M, Matokwani E, Mushimbalume M, Moraru Cl, Lehmanne J, Lassoie J, Wolfe D, Lee DR, Buck L, Travis AJ (2011) Community Markets for Conservation (COMACO) links biodiversity conservation with sustainable improvements in livelihoods and food production. Proceedings of the National Academy of Sciences 108:1395713962.

Lindgreen A, Antioco M, Harness D, van der Sloot R (2009a) Purchasing and Marketing of Social and Environmental Sustainability for High-Tech Medical Equipment. Journal of Business Ethics 85:445-462.

Lindgreen A, Swaen V, Johnston WJ (2009b) Corporate Social Responsibility: An Empirical Investigation of U.S. Organizations. Journal of Business Ethics 85:303-323.

Lock M (2004) Biomedical Technologies: Anthropological Approaches. In: Ember CR, Ember M (eds) Encyclopedia of Medical Anthropology, Klewer Press, New York, pp 86-95.

Mauro F, Hardison PD (2000) Traditional Knowledge of Indigenous and Local Communities: International Debate and Policy. Ecological Applications 10:1263-1269. 
Maybury-Lewis D (1997) Indigenous Peoples, Ethnic Groups, and The State: Cultural Studies in Ethnicity and Change. Allyn and Bacon, Boston, MA, USA

McHugh FP (1988) Keyguide to Information Sources in Business Ethics. Nichols Publishing, New York, USA.

Merson J (2000) Bio-Prospecting or Bio-Piracy: Intellectual Property Rights and

Biodiversity in a Colonial and Postcolonial Context. Osiris 15:282-296.

McGrath RG, Nerkar A (2004) Real Options Reasoning and a New Look at the R\&D Investment Strategies of Pharmaceutical Firms. Strategic Management Journal 25:1-21.

Millum J (2010) How Should the Benefits of Bioprospecting Be Shared? Hastings Center Report 40:24-33.

Moerman DE (1998) Native American Ethnobotany. Timber Press, Portland/Cambridge, USA, pp. 551-552.

Murrey F (2010) The Oncomouse That Roared: Hybrid Exchange Strategies as a Source of Distinction at the Boundary of Overlapping Institutions. The American Journal of Sociology 116:341-388.

Nazarea VD (2006) Local Knowledge and Memory in Biodiversity Conservation. Annual Review of Anthropology 35:317-35.

Newman DJ, Cragg GM (2007) Natural products as sources of new drugs over the last 25 years. Journal of Natural Products 70:461-477.

Nigh R (2002) Maya Medicine in the Biological Gaze: Bioprospecting Research as Herbal Fetishism. Current Anthropology 43:451-477

North DC (1990) Institutions, Institutional Change, and Economic Performance. Cambridge University Press, New York, USA

Novartis (2011) Novartis 2010 Global Reporting Initiative (GRI) Report. Novartis, Basel, Switzerland.

Peterson K (2001) Benefit Sharing for All?: Bioprospecting NGOs, Intellectual Property Rights, New Governmentalities. POLAR 24:78-91.

Porter M (1998) The Competitive Advantage of Nations. 2 edn. Free Press, New York, USA.

Posey DA (1985) Indigenous Management of Tropical Forest Ecosystems: The Case of the Kayapó Indians of the Brazilian Amazon. Agroforestry Systems 3:139-158.

Posey DA (1996) Traditional Resource Rights: International Instruments for Protection and Compensation for Indigenous People and Local Communities. IUCN and the World Conservation Union, Gland, Switzerland.

Prahalad CK (2004) The Fortune at the Bottom of the Pyramid: Eradicating Poverty through Profits. Wharton School Publishing, New York, USA.

Rausser GC, Small AA (2000) Valuing Research Leads: Bioprospecting and the Conservation of Genetic Resources. Journal of Political Economy 108:173-206

Roberts JT, Grimes PE (2002) World-system Theory and the Environment: Toward a new synthesis. In: Dunlap RE, Buttel FH, Dickens P, Gijwsijt A (eds) Sociological Theory and The Environment: Classical Foundations, Contemporary Insights. Rowman \& Littlefield, Lanham, MD, USA, pp. 167-194.

Roberts JT, Parks BC (2007) A climate of injustice: Global inequality, northsouth politics, and climate policy. MIT Press, Cambridge, MA, USA.

Roopnaraine T (1998) Indigenous Knowledge, Biodiversity and Rights. Anthropology Today 14:16.

Rosendal GK (2006) Regulating the Use of Genetic Resources - Between International Authorities. European Environment 16:265-277. 
Rotfeld HJ (2005) For the Drugs We Need. Journal of Consumer Marketing 22:365368.

Safrin S (2004) Hyperownership in a Time of Biotechnological Promise: The International Conflict to Control the Building Blocks of Life. The American Journal of International Law 98:641-685.

Schuklenk U, Kleinsmidt A (2006) North-South Benefit Sharing Arrangements in Bioprospecting and Genetic Research: A Critical Ethical and Legal Analysis. Developing World Bioethics 6:133-134.

Scott JC (1998) Seeing Like a State: How Certain Schemes to Improve the Human Condition Have Failed. Yale University Press, New Haven, CT, USA

Secretariat of the CBD (2011) Nagoya Protocol on Access to Genetic Resources and the Fair and Equitable Sharing of Benefits Arising from their Utilization to the Convention on Biological Diversity. United Nations Environmental Programme, Montreal.

Shiva V (1997) Biopiracy: The Plunder of Nature and Knowledge. South End Press, Cambridge, MA, USA.

Soejarto DD, Fong HH, Tan GT, Zhang HJ, Ma CY, Franzblau SG, Gyllenhaal C, Riley MC, Kadushin MR, Pezzuto JM, Xuan LT, Hiep NT, Hung NV, Vu BM, Loc PK, Dac LX, Binh LT, Chien NQ, Hai NV, Bich TQ, Cuong NM, Southavong B, Sydara K, Bouamanivong S, Ly HM, Thuy TV, Rose WC, Dietzman GR (2005) Ethnobotany/ethnopharmacology and mass bioprospecting: issues on intellectual property and benefit-sharing. Journal of Ethnopharmacology 100:15-22.

Stengers I (2005) The Cosmopolitical Proposal. In: Latour B, Weibel P (eds) Making Things Public: Atmospheres of Democracy. MIT Press, Cambridge, MA, USA.

Stigler GJ (1968) The Organization of Industry. Irwin, Homewood, IL, USA

Strangeland T, Dhillion SS, Reksten H (2008) Recognition and Development of Traditional Medicine in Tanzania. Journal of Ethnopharmacology 117:290-299

Verkman AS (2004) Drug Discovery in Academia. American Journal of PhysiologyCell Physiology 286:C465-C474

Walters D (2011) Plant Defense: Warding Off Attack by Pathogens, Herbivores and Parasitic Plants. Wiley-Blackwell, UK.

Warner JB (2006) Using Global Themes to Reframe the Bioprospecting Debate. Indiana Journal of Global Legal Studies 13:645-671.

Wazana A (2000) Physicians and The Pharmaceutical Industry: Is A Gift Ever Just A Gift? Journal of the American Medical Association, 283:373-380.

Williamson OE (1985) The Economic Institutions of Capitalism. Free Press, New York, USA.

Wines WA (2008) Seven Pillars of Business Ethics: Toward a Comprehensive Framework. Journal of Business Ethics 79:483-499.

Young T (Ed) (2009) Contracting for ABS: The Legal and Scientific Implications of Bioprospecting Contracts. IUCN, Gland, Switzerland. 